\begin{abstract}
Aktywność fizyczna osób z problemami onkologicznymi, uczestników Międzynarodowej Onko-Olimpiady Warszawa 2014

A - opracowanie koncepcji i założeń (preparing concepts)

B - opracowanie metod (formulating methods)

$\mathrm{C}$ - przeprowadzenie badań (conducting research)

D - opracowanie wyników (processing results)

E - interpretacja i wnioski (nterpretation and conclusions)

F - redakcja ostatecznej wersji (editing the final version)

\section{Physical activity of cancer survivors who participated in 2014 Warsaw International Onco-Olympics}

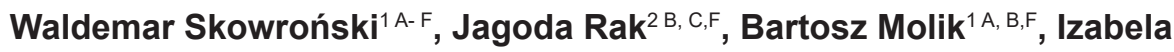

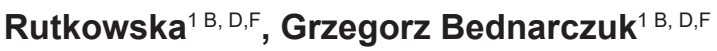 \\ ${ }^{1}$ Katedra Teorii i Metodyki Nauczania Ruchu, Akademia Wychowania Fizycznego \\ w Warszawie. Department of Theory and Methodology of Teaching Movement, \\ University of Physical Education in Warsaw \\ ${ }^{2}$ Fundacja Spełnionych Marzeń. Foundation of Fulfilled Dreams
}

\section{Streszczenie}

Wstęp: Celem było rozpoznanie i analiza zakresów, uwarunkowań i zróżnicowania aktywności fizycznej wśród sportowców z problemami onkologicznymi.

Materiat $i$ metody: Analizie poddano odpowiedzi na pytania ankiety uzyskane od 169 osób na 210 uczestników igrzysk Onko-Olimpiady (80 dziewcząt i 89 na 118 chłopców). Średnia wieku dziewcząt wynosiła 13,05 lat, a chłopców 13,08 lat. Reprezentowali Polskę (62 dziewcząt i 69 chłopców), Litwę (6 dziewcząt i 4 chłopców), Rumunię (4 dziewczęta i 8 chłopców), Ukrainę ( 8 dziewcząt i 8 chłopców). Zastosowano międzynarodowy kwestionariusz aktywności fizycznej (IPAQ).

Wyniki: Dziewczęta wykazały mniejszą intensywną (3,56 dnia/tyg. po $88 \mathrm{~min} / \mathrm{dzień})$ i umiarkowaną (3,61 dnia/tyg. po 96,5 min/dzień) aktywność fizyczną niż chłopcy (intensywna - 3,91 dnia/tyg. po 99,35 min/dzień., umiarkowana - 4,20 dnia/tyg. po 103,7 min/dzień). Czas chodzenia w tygodniu (dziewczęta - 16,18 godz., chłopcy - 15,91 godz.) i siedzenia (dziewczęta - 5,17 godz., chłopcy - 5,57 godz.). Wśród sportowców największą intensywną i umiarkowaną aktywność fizyczną wykazały osoby z nerwiakiem zarodkowym i nowotworem kości, a mniejszą osoby z białaczką, chłoniakiem i guzami litymi. Istniało zróżnicowanie aktywności fizycznej ze względu na rodzaj choroby nowotworowej.

Wnioski: Aktywność fizyczna sportowców z problemami onkologicznymi w Polsce nie zależy od płci, wieku w badanym jego zakresie, masy, wysokości ciała a także wskaźnika BMI, a zależy od rodzaju choroby nowotworowej. Istnieją przesłanki na przykładzie badanej grupy sportowców do różnicowania zalecanej aktywności fizycznej wyrażonej w MET-min./tyg. dla osób z różnymi rodzajami chorób onkologicznych.
\end{abstract}

onkologia, aktywność fizyczna, trening, dzieci

Praca została wykonana w ramach działalności statutowej Ds. 227 Akademii Wychowania Fizycznego w Warszawie w 2014 i 2016 roku. The research has been conducted within the statutory activity Ds. 227 of the Academy of Physical Education in Warsaw, years 2014 -2016. 


\section{Abstract}

Introduction: This study sought to identify and analyse the ranges, determinants and differences in physical activity levels of athletes with cancer.

Materials and methods: The analysis included questionnaire responses provided by 169 out of 210 participants of the Onco-Olympics ( 80 out of 92 girls and 89 out of 118 boys). The mean age was 13.05 years for girls and 13.08 years for boys. The study group consisted of the following participants: 62 girls and 69 boys from Poland, 6 girls and 4 boys from Lithuania, 4 girls and 8 boys from Romania and 8 girls and 8 boys from Ukraine. The International Physical Activity Questionnaire (IPAQ) was used in the study.

Results: Girls demonstrated lower levels of vigorous (3.56 days per week, 88 minutes per day) and moderate (3.61 days per week, 96.5 minutes per day) physical activity than boys (3.91 days per week, 99.35 minutes per day, and 4.20 days per week, 103.7 minutes per day, respectively). Walking time per week was 16.18 hours for girls and 15.91 hours for boys, while sitting time per week was 5.17 hours for girls and 5.57 hours for boys. Athletes with neuroblastoma and bone cancer displayed the highest levels of vigorous and moderate physical activity, while its lower levels were found in athletes with leukemia, lymphoma and solid tumors. Physical activity levels differed depending on the type of cancer.

Conclusions: Physical activity of Polish athletes with cancer does not depend on their sex, age in the examined range, body mass, body height or the BMI but it depends on the type of cancer.

Drawing on the example of the group of athletes under investigation, it is reasonable to assume that recommended physical activity levels (expressed in MET - minutes per week) ought to be different for persons with different types of oncological diseases.

Key words:

oncology, physical activity, training, children

\section{Wstęp}

Choroby onkologiczne są jednym z głównych problemów zdrowia publicznego. Zachorowalność na nowotwory złośliwe w Polsce wzrosła dwukrotnie od 1980 do 2010 roku. W roku 2010 wynosiła ponad 140,5 tys. zachorowań. W ciągu ostatniej dekady współczynnik zachorowalności w grupie wiekowej do 20 lat wynosił u obu płci około 11-13/105 [1]. Za jedną z wielu przyczyn ich coraz szerszego występowania uważane są niekorzystne zmiany w stylu życia ludzi, a szczególnie ograniczanie aktywności fizycznej [2]. Zawody sportowe dla dzieci i młodzieży po przebytej chorobie nowotworowej oraz same przygotowania do nich mogą być jednym z elementów kształtowania zdrowego stylu życia. Rywalizacja sportowa organizowana pod nazwą Onko-Olimpiada jest dobrym pretekstem do zwiększania aktywności fizycznej. Zawodnicy startują w biegach na 60 i 100 m, skoku w dal, pchnięciu kulą, rzucie piłeczką palantową, wyścigach na wózkach, pływaniu, tenisie stołowym i piłce nożnej. Zawody sportowe odbywają od 2007 r. Organizowane są przez Fundację Spełnionych Marzeń przy współpracy z Akademią Wychowania Fizycznego w Warszawie. Kolejne V Międzynarodowe Igrzyska Sportowe „Onko-Olimpiada 2014” odbyły się w dniach od 21 do 24 sierpnia w 2014 r.

\section{Introduction}

Oncological diseases are one of the main problems of public health. In Poland, malignant tumor morbidity doubled between 1980 and 2010. In 2010, there were over 140,500 new cases of the disease. In the last decade, the morbidity rate under the age of twenty years has been approx. 11-13/105 for both sexes [1]. Negative changes in lifestyle and limiting physical activity in particular are considered to be one of the many causes of more widespread occurrence of cancer [2]. Sporting events for children and youth who have survived cancer as well as competition-related preparations may be elements of a healthy lifestyle. A sporting event known as the Onco-Olympics provides a good opportunity to increase physical activity. Athletes compete in $60 \mathrm{~m}$ and $100 \mathrm{~m}$ races, long jump, shot put, cricket ball throw, wheelchair races, swimming, table tennis and football. The competition has been held since 2007 and it is organised by the Foundation of Fulfilled Dreams in cooperation with the University of Physical Education in Warsaw. The 5th International Onco-Olympic Games 2014 were held between 21st and 24th August 2014 in Warsaw. The competition included 210 male and female athletes from 16 
w Warszawie. Uczestnikami imprezy było 210 zawodników i zawodniczek z 16 ośrodków onkologicznych z Polski oraz Rumunii, Ukrainy, Litwy i Węgier.

Pozytywny wpływ aktywności fizycznej na zdrowie człowieka jest powszechnie akceptowany i stosowany w terapii wielu schorzeń, w tym również w zakresie chorób onkologicznych [2,3]. Początki badań na temat profilaktycznego znaczenia aktywności fizycznej w onkologii datowane są na 1922 r. Powstało bardzo wiele prac analizujących zależność między aktywnością fizyczną a profilaktyką raka, ale dokładne dane na temat typu, intensywności i obciążeń niezbędnych do ochrony przed rakiem nie są w pełni poznane $[4,5]$. Badacze koncentrują swoją uwagę na profilaktyce i potencjalnym ryzyku raka związanym z brakiem aktywności fizycznej [2]. Badanie aktywności fizycznej osób z problemami nowotworowymi jest ciągle aktualnym problemem badawczym. Aktywność fizyczna jest prawdopodobnie najlepszym i najmniej docenianym środkiem rehabilitacji i poprawy stanu organizmu u osób z problemami onkologicznymi. Zakresy prowadzonych badań nad programami interwencji ćwiczeniami fizycznymi u osób z rakiem nie dają jednoznacznych odpowiedzi co do poziomu aktywności fizycznej i uzyskiwanych efektów zdrowotnych [6,7].

Porównanie realizowanej aktywności fizycznej przez zawodników przygotowujących się do startu w Onko-Olimpiadzie do zalecanego jej minimalnego poziomu dla osób z problemami onkologicznymi pozwoli na uświadomienie możliwości zwiększania aktywności fizycznej również dla tych osób z problemami onkologicznymi, które sportu nie uprawiają [2,6].

Celem poznawczym badań było określenie poziomu tygodniowej aktywności fizycznej na tle zaleceń American College of Sports Medicine (ACSM) (5), zawodniczek i zawodników przygotowujących się do Onko-Olimpiady 2014 z uwzględnieniem podziału na płeć. Innym celem było określenie zależności aktywności fizycznej od wieku, masy, wysokości ciała i wskaźnika masy ciała BMI oraz rodzaju schorzenia.

Celem praktycznym było stworzenie przesłanek do zaleceń aktywności fizycznej dzieci i młodzieży z problemami onkologicznymi uprawiających aktywność sportową.

\section{Materiał i metody}

Analizie poddano odpowiedzi na pytania ankiety uzyskane od 169 osób na 210 uczestników OnkoOlimpiady w Warszawie w 2014 r. (80 na 92 dziewcząt i 89 na 118 chłopców). Średnia wieku badanych dziewcząt wynosiła 13,05 lat, a chłopców 13,08 lat. Reprezentowali Polskę (62 na 71 dziewcząt z Polski i 69 na 88 chłopców z Polski), Litwę ( 6 dziewcząt i 4 chłopców), Rumunię (4 dziewczęta i 8 chłopców), oncological centres in Poland, Romania, Ukraine, Lithuania and Hungary.

Positive effects of physical activity on human health are widely recognised and implemented when treating a number of diseases including cancer $[2,3]$. The first studies referring to the preventive role of physical activity in oncology date back to 1922. A lot of studies have focused on correlations between physical activity and cancer prevention; however, types, intensity and loads useful in cancer prevention have not been fully investigated as yet $[4,5]$. Researchers focus on prevention and potential cancer risk linked to the lack of physical activity [2]. The investigation of physical activity of cancer survivors is still a current scientific problem. Physical activity is probably the best yet the least recognised means of rehabilitation and improvement for persons with oncological problems. The scope of the research on intervention programmes and physical exercises in cancer survivors does not provide conclusive evidence regarding physical activity levels and obtained health-related effects [6,7].

The comparison between the levels of physical activity in athletes preparing to participate in the Onco-Olympics and recommended minimum physical activity levels for cancer survivors will help to recognise the potential of increasing physical activity also among those persons with oncological problems who do not practise any sports $[2,6]$.

The cognitive aim of the study was to determine levels of weekly physical activity with reference to recommendations of the American College of Sports Medicine (ACSM) (5) of female and male athletes preparing to participate in the 2014 Onco-Olympics taking into consideration their sex. Another aim was to determine correlations between physical activity levels and age, body mass, body height, BMI and the type of cancer.

A practical objective was to provide the basis for developing physical activity guidelines for children and youth with oncological problems who practise sports.

\section{Material and methods}

The analysis included questionnaire responses provided by 169 out of 210 participants of the 2014 Warsaw Onco-Olympics (80 out of 92 girls and 89 out of 118 boys). The mean age was 13.05 years for girls and 13.08 years for boys. The study group consisted of the following participants: 62 out of 71 girls and 69 out of 88 boys from Poland, 6 girls and 4 boys from Lithuania, 4 girls and 8 boys from Romania and 8 girls and 8 boys from Ukraine. Hungarian athletes (3 girls and 10 boys) did not provide any questionnaire responses. 
Ukrainę ( 8 dziewcząt i 8 chłopców). Węgrzy nie udzielili odpowiedzi na ankiety (3 dziewczęta i 10 chłopców). W zawodach startowali sportowcy od 6 do 23 roku życia (tabela 1). Średnia wieku zawodniczek polskich wynosiła $12,81+3,68$, a zawodników $12,67+3,34$. Nie było między zawodniczkami i zawodnikami istotnych statystycznie różnic, podobnie jak u zawodniczek i zawodników zagranicznych.

Struktura wiekowa badanych zawodników polskich, według kategorii wiekowych stosowanych w Onko-Olimpiadach była następująca: dziewczęta 6 - 9 lat $-11,3 \% ; 10-12$ lat $-16,1 \% ; 13-15$ lat $-43,6 \%$; 16 lat i powyżej - 29,0\% oraz chłopcy 6 - 9 lat $-15,9 \% ; 10-12$ lat $-14,5 \% ; 13-15$ lat - 45,0\%; 16 lat i powyżej - 24,6\%. Najwięcej badanych osób wśród chłopców i dziewcząt z Polski było w kategoriach 13-15 oraz 16 i więcej lat.

Najczęściej występującą chorobą u badanych była białaczka (29 dziewcząt i 31 chłopców), następnie chłoniak (8 dziewcząt i 17 chłopców), nowotwór kości (7 dziewcząt i 7 chłopców), guz lity (3 dziewczęta i 5 chłopców), nerwiak zarodkowy (4 dziewczęta i 2 chłopców) i guz mózgu ( 2 dziewczynki i 4 chłopców), ziarniak kwasochłonny (2 chłopców), hemofilia (1 chłopiec). U dziewięciu dziewcząt nie podano rodzaju choroby nowotworowej.
Athletes between 6 and 23 years of age took part in the competition (table 1). The mean age of Polish female and male competitors was $12.81+3.68$ and $12.67+3.34$, respectively. Similar to their foreign female and male counterparts, there were no significant differences between Polish female and male athletes.

The age structure of the Polish athletes (according to age categories used in the Onco-Olympics) was as follows: girls $6-9$ years $-11.3 \%$; $10-12$ years $-16.1 \%$; $13-15$ years $-43.6 \%$; 16 years and above $-29.0 \%$, and boys $6-9$ years $-15.9 \%$; $10-12$ years $-14.5 \%$; $13-15$ years $-45.0 \%$; 16 years and above $-24.6 \%$. As for the Polish athletes, they mainly belonged to age groups of 13-15 years and 16 years and above.

Leukemia was the most common disease in the study group (29 girls and 31 boys) followed by lymphoma ( 8 girls and 17 boys), bone cancer ( 7 girls and 7 boys), solid tumor (3 girls and 5 boys), neuroblastoma ( 4 girls and 2 boys), brain tumor ( 2 girls and 4 boys), eosinophilic granuloma (2 boys) and haemophilia (1 boy). Nine girls did not state the type of cancer.

The International Physical Activity Questionnaire (IPAQ) including questions regarding vigorous and moderate physical activity as well as time spent walking or sitting (at least 10 minutes) was employed in the study [8]. Its reliability and validity was determined

Tab. 1. Liczba osób i charakterystyki wieku badanych grup z podziałem na płeć

Tab. 1. Number of persons and the characteristics of the age groups studied by gender

\begin{tabular}{|l|c|c|c|}
\hline Badani/Respondents & n & & Maks. - Min. \\
\hline Dziewczęta Polska/Girls Poland & 62 & $12,81 \pm 3,68$ & $23-6$ \\
\hline Chlopcy Polska/Boys Poland & 69 & $12,67 \pm 3,34$ & $17-6$ \\
\hline Dziewczęta Litwa/Girls Lithuania & 6 & $11,17 \pm 3,29$ & $14-11$ \\
\hline Chlopcy Litwa/Boys Lithuania & 4 & $12,75 \pm 1,09$ & $17-13$ \\
\hline Dziewczęta Rumunia/Girls Romania & 4 & $15,25 \pm 1,48$ & $18-15$ \\
\hline Chlopcy Rumunia/Boys Romania & 8 & $16,00 \pm 1,12$ & $18-10$ \\
\hline Dziewczęta Ukraina/Girls Ukraine & 8 & $13,63 \pm 3,04$ & $17-10$ \\
\hline Chlopcy Ukraina/Boys Ukraine & 8 & $13,75 \pm 2,82$ & \\
\hline
\end{tabular}

$\mathrm{n}$ - liczba badanych/number of respondents;

średnia wieku/mean age; Maks. - wiek osoby najstarszej/age of the oldest; Min. - wiek osoby najmłodszej/age of the youngest

Zastosowano Międzynarodowy Kwestionariusz Aktywności Fizycznej (IPAQ) zawierający pytania dotyczące intensywnej i umiarkowanej aktywności fizycznej oraz czasu spędzonego na chodzeniu i siedzeniu (minimum 10 min. aktywności) [8]. Trafność i rzetelność została opisana zbadana na podstawie 12 krajów Europy [9]. Kwestionariusz ten został uznany za jeden z najbardziej wartościowych dla wykonywania masowych badań aktywności fizycznej [10]. Metoda sondażu diagnostycznego techniką kwestionariuszową pozwoliła zebrać dane na temat aktywności fizycznej od większości uczestników OnkoOlimpiady 2014 roku. Badani i ich rodzice (opiekunowie prawni) wyrazili zgodę na udział w badaniu, a następnie wypełnili kwestionariusz i przesłali go do organizatora wraz ze zgłoszeniem do zawodów. on the basis of data gathered in 12 European countries [9]. The questionnaire was found to be one of the most valuable instruments for large-scale assessment of physical activity [10]. A diagnostic survey method made it possible to collect data on physical activity of the majority of 2014 Onco-Olympics participants. The study participants and their parents (legal guardians) gave their informed consent to take part in the study. After that, they filled in the questionnaire and sent it together with the competition registration form to the organisers of the event. The research was conducted within statutory activity DS. 227, which was approved by the Ethics Committee of the University of Physical Education in Warsaw.

Units expressed in MET (minutes per week) as well as activity defined by the number of days per week and 
Badania wykonano w ramach badań statutowych Ds. 227, które uzyskały zgodę Senackiej Komisji Etyki Badań Naukowych Akademii Wychowania Fizycznego w Warszawie.

Do analiz aktywności fizycznej użyto jednostek wyrażonych w MET min/tydzień oraz aktywność określoną liczbą dni/tyg., a także liczbą min./dzień. Równoważnik metaboliczny 1 MET odpowiada zużyciu tlenu w spoczynku i wynosi $3,5 \mathrm{ml} \mathrm{O} 2 / \mathrm{kg}$ masy ciała/min. Przyjęto, że wartości współczynnika MET dla chodzenia to 3,3, wysiłku umiarkowanego 4,0 i intensywnego 8,0 [8, 11].

Aktywność fizyczną badanych osób zakwalifikowano do jednej z trzech grup [12]:

- wysoka - wykonywanie trzy razy w tygodniu intensywnych wysiłków z wydatkiem minimum 1500 MET min/tyg. lub codziennie umiarkowanych wysiłków lub chodzenia na poziomie minimum 3000 MET min/tyg.

- umiarkowana - co najmniej trzy dni w tygodniu intensywna aktywność przez 20 min. lub 5 dni w tygodniu aktywność umiarkowana, lub chodziły co najmniej przez 30 min dziennie a wydatek energetyczny pochłaniał od 600 do 1500 MET min/tyg. - niska - aktywność z wydatkiem energetycznym poniżej $600 \mathrm{MET}$ min/tyg.

Ze względu na małe liczebności zawodników zagranicznych postanowiono przedstawić porównania tylko całkowitych wskaźników aktywności fizycznej między reprezentantami różnych krajów. Natomiast szczegółowe analizy zależności aktywności fizycznej od płci, wieku, masy, wysokości ciała, wskaźnika BMI i rodzaju choroby nowotworowej dotyczyły zawodników reprezentujących Polskę.

Wszystkie obliczenia i analizy statystyczne wykonano przy pomocy programu komputerowego SPSS 20.

\section{Wyniki}

Tab. 2. Statystyki opisowe masy [kg], wysokości ciała [cm] i wskaźnika BMI

Tab. 2. Descriptive statistics weight, body height and BMI

\begin{tabular}{|c|c|c|c|c|c|c|}
\hline \multirow[t]{2}{*}{ Badani/Respondents } & \multicolumn{2}{|c|}{ Masa ciala/Body weight } & \multicolumn{2}{|c|}{ Wysokość ciała/Body height } & \multicolumn{2}{|c|}{ BMI } \\
\hline & & Maks. - Min. & & Maks. - Min. & & Maks. - Min. \\
\hline Dziewczęta Polska/Girls Poland & $44,20 \pm 14,91$ & $90-16$ & $150,64 \pm 17,15$ & $178-104$ & $18,87 \pm 3,53$ & $30,42-11,55$ \\
\hline Chłopcy Polska/Boys Poland & $46,40 \pm 15,72$ & $81-15$ & $155,12 \pm 18,39$ & $187-106$ & $18,68 \pm 3,23$ & $30,48-13,35$ \\
\hline Dziewczęta Litwa/Girls Lithuania & $33,33 \pm 10,32$ & $50-20$ & $142,67 \pm 19,31$ & $176-120$ & $16,02 \pm 2,00$ & $19,53-13,89$ \\
\hline Chłopcy Litwa/Boys Lithuania & $43,75 \pm 16,54$ & $67-21$ & $150,00 \pm 20,24$ & $173-122$ & $18,54 \pm 3,14$ & $22,39-14,11$ \\
\hline Dziewczęta Rumunia/Girls Romania & $51,75 \pm 2,86$ & $55-48$ & $161,00 \pm 3,94$ & $165-155$ & $19,95 \pm 0,25$ & $20,20-19,53$ \\
\hline Chłopcy Rumunia/Boys Romania & $60,38 \pm 13,73$ & $78-37$ & $171,00 \pm 11,65$ & $183-150$ & $20,34 \pm 2,61$ & $24,07-16,18$ \\
\hline Dziewczęta Ukraina/Girls Ukraine & $44,50 \pm 13,37$ & $65-27$ & $155,00 \pm 8,73$ & $165-136$ & $18,17 \pm 3,95$ & $24,46-13,85$ \\
\hline Chlopcy Ukraina/Boys Ukraine & $53,88 \pm 18,11$ & $90-34$ & $163,75 \pm 17,98$ & $195-142$ & $19,68 \pm 4,31$ & $29,39-15,33$ \\
\hline
\end{tabular}

średnia /mean; Maks. - wartość największa/Maximum value; Min. - wartość najmniejsza/Minimum value the number of minutes per day were used to analyse physical activity levels. One metabolic equivalent of task (1 MET) refers to oxygen consumption at rest and is equal to $3.5 \mathrm{ml} \mathrm{O} 2 / \mathrm{kg}$ of body mass $/ \mathrm{min}$. It was assumed that MET values ranged from 3.3 (walking) through 4.0 (moderate activity) to 8.0 (vigorous activity) $[8,11]$.

Physical activity of the study participants was placed at one of the three levels [12]:

- high - vigorous activity three times a week, with a minimum expenditure of 1500 MET (minutes per week) or daily moderate activity or walking with a minimum expenditure of 3000 MET (minutes per week).

- moderate - vigorous activity for 20 minutes at least three times a week or moderate activity five times a week or daily walking for at least 30 minutes, with energy expenditure of 600 to 1500 MET (minutes per week).

- low - activity with energy expenditure below 600 MET (minutes per week).

Due to a small number of foreign competitors, only comparisons of total physical activity indices between athletes from different countries were presented. In the case of the Polish competitors, though, detailed analyses of correlations between physical activity levels and sex, age, body mass, body height, BMI and the type of cancer were made.

All calculations and statistical analyses were performed using SPSS 20 software.

\section{Results}

Descriptive statistics of body mass, body height and BMI of athletes from different countries can be found in table 2. Female competitors were smaller and lighter than male athletes, yet the differences were not significant. BMI in girls and boys was at a similar level $-18.87+3.53$ and $18.68+3.23$, respectively. 
Statystyki opisowe masy, wysokości i wskaźnika BMI zawodników z różnych krajów przedstawiono w tabeli 2 . Zawodniczki były niższe i lżejsze niż zawodnicy, ale różnice nie były istotne statystycznie. Wskaźniki BMI były na podobnym poziomie u dziewcząt - 18,87+3,53 i u chłopców 18,68+3,23.

Całkowita aktywność fizyczna reprezentantów różnych krajów na tle zaleceń ACSM wyrażona w MET min/ tyg., została przedstawiona na ryc. 1. Wszyscy uczestnicy Onko-Olimpiady 2014 byli aktywni fizycznie na poziomie przekraczającym kilka razy zalecenia aktywności w prewencji chorób. Najwyższy poziom całkowitej aktywności fizycznej prezentowali chłopcy z Ukrainy, potem Ruminii i Litwy, a Polacy relatywnie najniższy. Natomiast wśród dziewcząt najwyższą aktywność miały te z Ukrainy potem z Polski, Litwy i Rumunii.
Total physical activity of representatives of different countries (according to ACSM guidelines) expressed in MET (minutes per week) is illustrated in figure 1. All Onco-Olympians were physically active at a level which was a few times higher than activity-related recommendations for disease prevention. The highest levels of physical activity were noted in boys from Ukraine, followed by their counterparts from Romania and Lithuania, while the lowest levels were found in boys from Poland. As far as girls are concerned, the highest levels of physical activity were observed in athletes from Ukraine, followed by their peers from Poland, Lithuania and Romania.

The percentage of Polish Onco-Olympians with regard to physical activity levels is presented in figure 2 . Girls (66.7\%) and boys (66.2\%) were usually highly

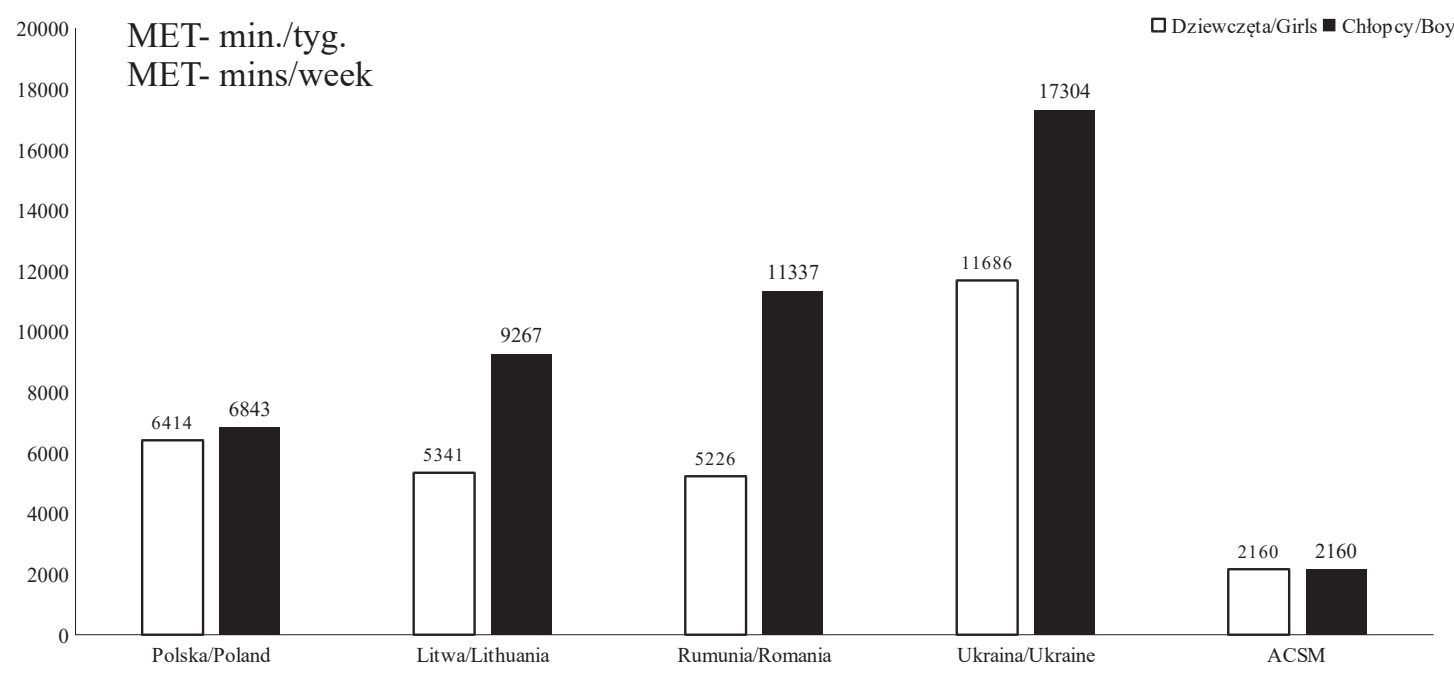

Ryc. 1. Całkowita aktywność fizyczna uczestników Onko-Olimpiady 2014 z różnych krajów

Fig. 1. The total physical activity [MET mins/week] Onco - Olympics participants from different countries in 2014

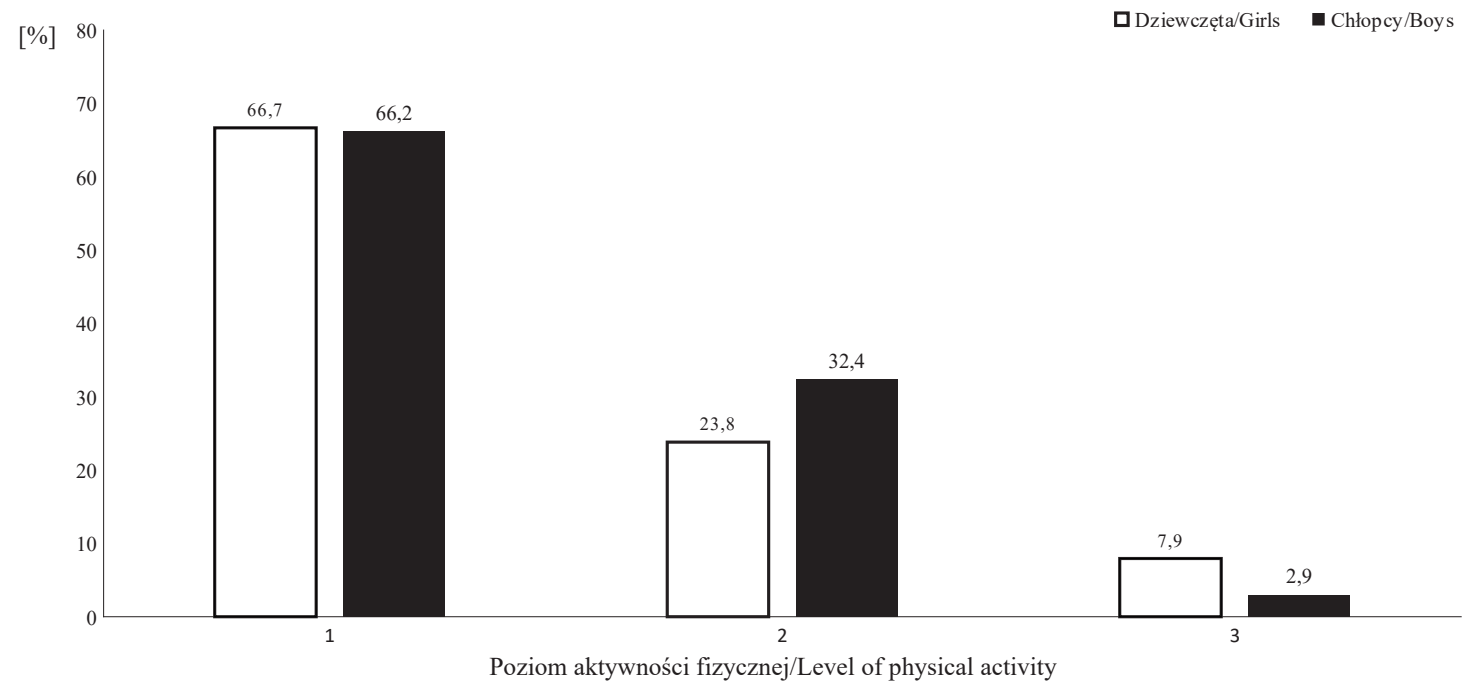

Ryc. 2. Odsetek uczestników Onko-Olimpiady z Polski według poziomów aktywności fizycznej

Fig. 2. The percentage of Onco - Olympics participants from Polish by levels of physical activity 
Odsetek uczestników Onko-Olimpiady z Polski według poziomów aktywności fizycznej przedstawiono na rycinie 2. Dziewczęta $(66,7 \%)$ i chłopcy $(66,2 \%)$ najczęściej byli aktywni na wysokim poziomie. Umiarkowany poziom aktywności wykazało $23,8 \%$ dziewcząt, a 32,4\% chłopców. Niski poziom aktywności dotyczył 7,9\% dziewcząt i 2,9\% chłopców.

Relacje między rodzajami chorób nowotworowych, a poziomem całkowitej aktywności fizycznej uczestników z Polski przedstawiono na rycinie 3 . Wśród chłopców można zauważyć, że najwyższy poziom prezentowały osoby z nowotworem kości i ziarniakiem kwasochłonnym. Drugą niższą grupą aktywności fizycznej charakteryzowały się osoby z chłoniakiem, białaczką i nerwiakiem zarodkowym. Relatywnie najniższy poziom aktywności prezentowały osoby z guzem mózgu, guzem litym oraz hemofilią.

Wśród dziewcząt widoczna była najniższa aktywność, podobnie jak u chłopców, także u osób z guzem mózgu i guzem litym oraz chłoniakiem. Wysoka aktywność dziewcząt była u tych z nerwiakiem zarodkowym, a średnia z rakiem kości i białaczką. active. Moderate levels of physical activity were revealed by $23.8 \%$ of the girls and $32.4 \%$ of the boys. Low levels of physical activity were found in $7.9 \%$ of the girls and $2.9 \%$ of the boys.

Correlations between the types of cancer and total physical activity levels of the Polish participants are shown in figure 3 . In the case of the boys, it can be noted that persons with bone tumors and eosinophilic granuloma manifested the highest levels of physical activity. Lower physical activity levels were observed in persons with lymphoma, leukemia and neuroblastoma, while relatively the lowest physical activity levels were exhibited by persons with brain tumors, solid tumors and haemophilia.

Similar to the boys, the girls with brain tumors and solid tumors as well as the girls with lymphoma demonstrated the lowest levels of physical activity. High physical activity levels were found in the girls with neuroblastoma, whereas moderate levels were noted in the girls with bone tumors and leukemia.

Correlations between total physical activity and age, body mass, body height and BMI proved insignif-

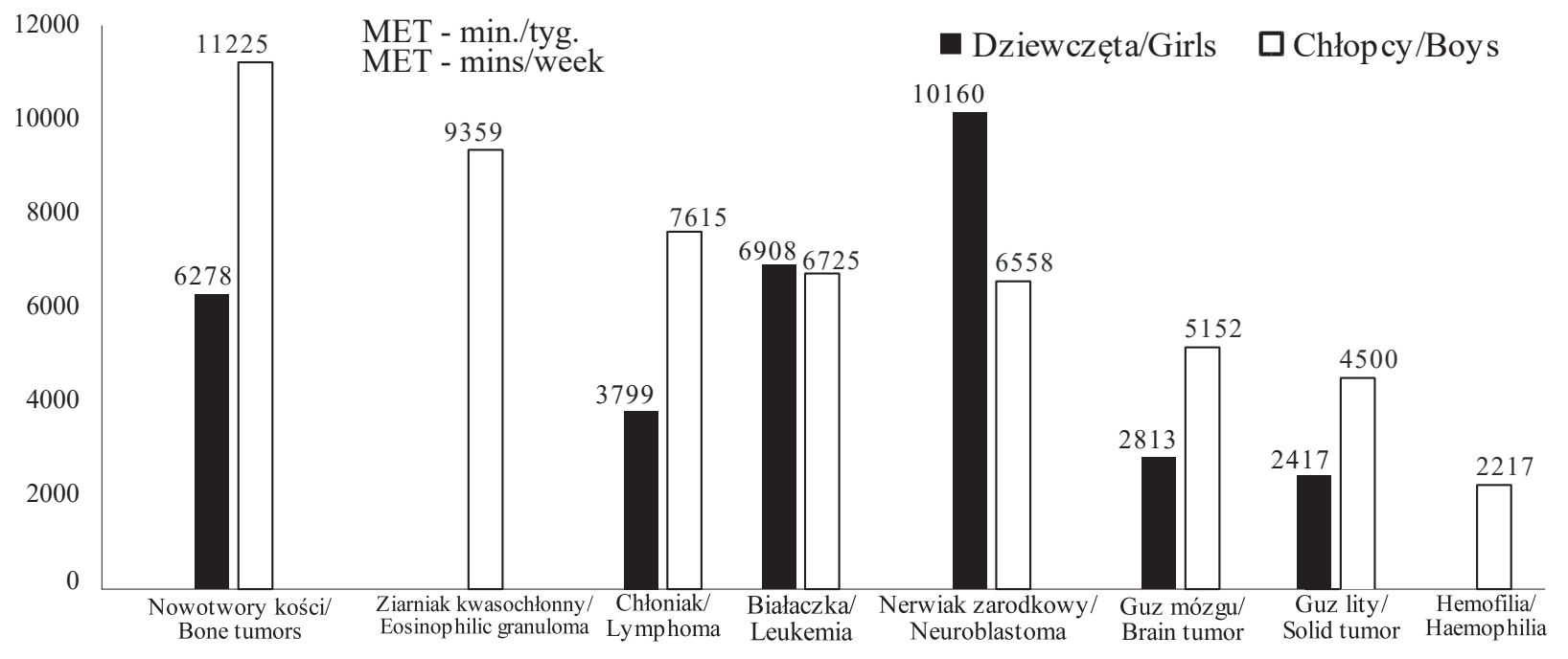

Ryc. 3. Całkowita aktywność fizyczna uczestników Onko-Olimpiady z Polski według rodzajów chorób nowotworowych Fig. 3. The total physical activity Onco-Olympics participants from Polish by type of cancer

Korelacje między wiekiem, masą i wysokością ciała i wskaźnikami BMI a całkowitą aktywnością fizyczną okazały się nie istotne statystycznie $\mathrm{z}$ wyjątkiem BMI u chłopców (tabela 3). Wszystkie badane korelację u dziewcząt były ujemne (od $-0,275$ do $-0,178$ ), a u chłopców dodatnie (od 0,196 do 0,402). icant, with the exception of BMI in boys (table 3). All the examined correlations were negative in girls (from -0.275 to -0.178 ) and positive in boys (from 0.196 to $0.402)$.

Table 4 shows physical activity expressed in days per week and minutes per day for vigorous activity,

Tab. 3. Współczynniki korelacji Pearsona dla całkowitej aktywności fizycznej w MET - min./tyg. i badanych zmiennych

Tab. 3. Pearson correlation coefficients for total physical activity in MET - min./week and the variables examined

\begin{tabular}{|l|c|c|}
\hline Zmienna/Variable & Dziewczęta/Girls & Chłopcy/Boys \\
\hline Wiek w latach/Age in yers & $-0,266$ & 0,196 \\
\hline Masa ciała w kg/Body mass in kg & $-0,275$ & 0,259 \\
\hline Wysokość ciała w cm/Body height in cm & $-0,270$ & 0,344 \\
\hline BMI & $-0,178$ & $0,402 *$ \\
\hline
\end{tabular}

* korelacja jest istotna na poziomie 0,05 (dwustronnie) 
Tab. 4. Liczba dni i czas poświęcony rożnym poziomom aktywności fizycznej

Tab. 4. Number of days and time devoted to different levels of physical activity

\begin{tabular}{|l|c|c|c|c|c|}
\hline \multirow{2}{*}{ Poziom aktywności/The level of activity } & \multirow{2}{*}{ Jednostka/Unit } & \multicolumn{2}{|c|}{ Dziewczęta/Girls } & \multicolumn{2}{c|}{ Chlopcy/Boys } \\
\cline { 3 - 6 } & & & Maks. - Min. & \multicolumn{2}{c|}{ Maks. - Min. } \\
\hline \multirow{2}{*}{ Intensywna/ Intense } & Dni/tyg,/Days/weeks & $3,24+1,84$ & $7-1$ & $3,72+1,99$ & $7-1$ \\
\cline { 2 - 6 } & Min./dzień/Min./Day & $79,00+65,11$ & $300-10$ & $88,49+66,82$ & $300-10$ \\
\hline \multirow{2}{*}{ Umiarkowana/ Moderate } & Dni/tyg,/Days/weeks & $3,62+1,84$ & $7-1$ & $4,11+1,91$ & $7-1$ \\
\cline { 2 - 6 } & Min./dzień/Min./Day & $100,57+75,33$ & $360-10$ & $99,15+71,98$ & $360-15$ \\
\hline \multirow{2}{*}{ Chodzenie/Walk } & Dni/tyg,/Days/weeks & $6,39+1,31$ & $7-2$ & $6,12+1,74$ & $7-1$ \\
\cline { 2 - 6 } & Min./dzień/Min./Day & $162,03+150,23$ & $600-10$ & $150,79+157,75$ & $600-15$ \\
\hline \multirow{2}{*}{ Siedzenie/Seat } & Dni/tyg,/Days/weeks & $7,00+0$ & $7-7$ & $7,00+0$ & $7-7$ \\
\cline { 2 - 6 } & Min./dzień/ Min./Day & $309,81+159,05$ & $600-10$ & $335,34+151,40$ & $840-40$ \\
\hline
\end{tabular}

W tabeli 4 przedstawiono aktywność fizyczną wyrażoną $\mathrm{w}$ dniach/tyg. oraz $\mathrm{w}$ min./dzień dla aktywności intensywnej, umiarkowanej, chodzenia i siedzenia. Generalnie nie stwierdzono różnic istotnych statystycznie między dziewczętami i chłopcami. Natomiast istnieje tendencja do większej liczby dni i minut dziennie poświęcanych aktywności intensywnej i liczby dni aktywności umiarkowanej wśród chłopców. Dziewczęta nieco więcej dni oraz minut dziennie chodziły, a chłopcy więcej minut dziennie poświęcali na siedzenie.

\section{Dyskusja}

W ostatnich dekadach nastąpił znaczny postęp w zakresie oceny aktywności fizycznej u osób z chorobami onkologicznymi [13]. Korzyści wynikające z aktywności fizycznej są coraz powszechniej znane [6]. Zalecenia ACSM dla osób z problemami onkologicznymi to między innymi minimum $150 \mathrm{~min}$. w tygodniu ćwiczeń o średniej intensywności oraz minimum 75 min. z dużą intensywnością. Czas trwania jednych zajęć powinien wynosić od 20 do $60 \mathrm{~min}$ [5].

Z prezentowanych badań wynika, że dziewczęta i chłopcy w większości realizowali zalecane czasy trwania w tygodniu wysiłków intensywnych i umiarkowanych. Jednak są też tacy, którzy tych zaleceń nie wypełniali. Generalnie dziewczęta były nieco mniej aktywne od chłopców.

Praca dostarczyła danych o aktywności fizycznej zawodników przygotowujący się do startu w zawodach, a wiec prawdopodobnie bardziej aktywnych niż to ma miejsce przeciętnie. Wnioski z takich informacji pozwalają na wskazanie możliwego zakresu aktywności fizycznej również dla tych, którzy nie uprawiają sportu.

Przedstawione wyniki badań aktywności fizycznej uczestników Onko-Olimpiady były analizowane na podstawie ich subiektywnej oceny. Jest to ograniczenie prezentowanych badań. Podobnie jak fakt, że w badaniach uczestniczyły, co prawda w niewielkim odsetku też osoby $\mathrm{z}$ młodszych kategorii wie- moderate activity, walking and sitting. In general, no significant differences between girls and boys were observed. However, boys devoted more days per week and more minutes per day to vigorous activity as well as more days per week to moderate activity. Girls spent more days and minutes per day walking, while boys spent more minutes per day sitting.

\section{Discussion}

Over the past few decades, considerable progress was made in terms of assessing physical activity of persons with cancer [13]. Benefits of physical activity are more and more recognised [6]. According to ACSM guidelines, cancer survivors should perform moderate-intensity exercises for at least 150 minutes per week and vigorous exercises for at least 75 minutes per week. The duration of each workout should range from 20 to 60 minutes [5].

Our findings indicate that most girls and boys performed vigorous and moderate-intensity exercises in compliance with the above-mentioned recommendations. However, some study participants did not follow these guidelines. In general, girls were slightly less active than boys.

The data gathered in the course of the investigation concerned physical activity of athletes preparing to participate in a competition, i.e. individuals who are probably more active than untrained persons. The conclusions enable us to indicate possible ranges of physical activity also for those who do not practise any sports.

The results of the research on physical activity of the participants of the Onco-Olympics were analysed on the basis of their own subjective assessment, which is a limitation of the study. Furthermore, there was also a small percentage of the study participants from younger age categories, i.e. 6-9 years (girls 11.3\%, boys $15.9 \%$ ) and $10-12$ years (girls $16.1 \%$, boys $14.5 \%$ ). In order to increase objectivity, the IPAQ questionnaire ought to be supplemented with more objective methods, e.g. monitoring with the use of elec- 
kowych od 6 do 9 lat (dziewczęta 11,3\%, chłopcy 15,9\%) oraz 10-12 lat (dziewczęta 16,1\%, chłopcy $14,5 \%$ ). W celu większej obiektywizacji danych kwestionariusz IPAQ powinien być uzupełniony bardziej obiektywnymi metodami jak np. monitoring przy pomocy urządzeń elektronicznych czy badań fizjologicznych. Trzeba też w przyszłości uwzględnić strukturę wiekową badanej grupy i liczebność osób z różnymi rodzajami chorób nowotworowych. Można jednak przy pomocy wykonanej analizy opinii uczestników Onko-Olimpiady zwrócić uwagę na ogólne zjawiska i zależności. Przykładowo, zauważalne było zróżnicowanie aktywności fizycznej w zależności od rodzaju choroby onkologicznej.

\section{Wnioski}

Najważniejsze wnioski z przeprowadzonej analizy materiału to:

1. Aktywność fizyczna sportowców z problemami onkologicznymi w Polsce nie zależy od płci, wieku w badanym jego zakresie, masy, wysokości ciała a także wskaźnika BMI, a zależy od rodzaju choroby nowotworowej.

2. Istnieją przesłanki na przykładzie badanej grupy sportowców do różnicowania zalecanej aktywności fizycznej wyrażonej w MET-min./tyg. dla osób z różnymi rodzajami chorób onkologicznych.

3. Zawodniczki i zawodnicy Onko-Olimpiady 2014 realizowali w większości przypadków zalecenia ACSM w zakresie czasu trwania wysiłku, co stanowi o dużej wartości i znaczeniu udziału w ruchu Onko-Olimpiady. tronic devices or physiological examinations. Further studies should include the age structure of the studied population and the number of persons with different types of cancer. Nevertheless, the analysis of opinions expressed by Onco-Olympians shows general trends and correlations. For instance, differences in physical activity levels depending on the type of cancer can be noted.

\section{Conclusions}

The data analysis led to the following conclusions:

1. Physical activity of Polish athletes with cancer does not depend on their sex, age (in the examined range), body mass, body height or BMI but it depends on the type of cancer.

2. Drawing on the example of the group of athletes under investigation, it is reasonable to assume that recommended physical activity levels (expressed in MET - minutes per week) ought to be different for persons with different types of oncological diseases.

3. In most cases, female and male competitors of the 2014 Onco-Olympics followed ACSM recommendations in terms of activity duration, which shows a great value and significance of participating in the Onco-Olympics movement.

\section{Piśmiennictwo/References}

1. Didkowska J, Wojciechowska U. Zachorowania i zgony na nowotwory złośliwe w Polsce [Internet]. Warszawa: Krajowy Rejestr Nowotworów, Centrum Onkologii - Instytut im. Marii Skłodowskiej - Curie; c 2013 [updated 2013 Jul 31; cited 2015 Jul 10]. Available from: http://onkologia.org.pl/nowotwory-zlosliwe-ogolem-2/

2. Kruk J, Hassan Y, Aboul-Enein H Y. The role of physical activity in the prevention of cancer. Cancer Therapy. 2007; 5:169180.

3. Winnick JP. Adapted Physical Education and Sport. 4 ed. Champaign: Human Kinetics; 2005.

4. McTiernan A. Interwention studies in exercise and cancer prevention. Med Sci Sports Exerc. 2003; 35:1841-1845.

5. Lee IM. Physical activity and cancer prevention: data from epidemiologic studies. Med Sci Sports Exerc. 2003; 35(11):1823-7.

6. Schmitz KH, Courneya KS, Matthews C, Demark-Wahnefried W, Galvão DA, Pinto BM, at al. American College of Sports Medicine roundtable on exercise guidelines for cancer survivors. Med Sci Sports Exerc. 2010; 42:1409-1426.

7. Speck R M, Courneya K S, Mâsse L C, Duval S, Schmitz KH. An update of controlled physical activity trials in cancer survivors: a systematic review and meta-analysis. J Cancer Surviv, 2010; 4:87-100.

8. Biernat E, Stupnicki R, Gajewski A K. Międzynarodowy Kwestionariusz Aktywności Fizycznej (IPAQ) - wersja polska. Wychowanie Fizyczne i Sport. 2007; 51(1):47-54.

9. Craig CL, Marshall AJ, Sjöström M, Bauman AE, Booth ML, Ainsworth BE, at al. International Physical Activity Questionnaire: 12-country reliability and validity. Med Sci Sports Exerc. 2003; 35(8):1381-1395.

10. Booth M L. Assessment of physical activity: an international perspective. Res.Q.Exerc.Sport. 2000; 71:114-120.

11. Biernat E. Międzynarodowy Kwestionariusz Aktywności Fizycznej - Polska długa wersja. Medycyna Sportowa. 2013; 1(4), Vol. 29:1-15.

12. Piątkowska M. Wiek jako czynnik różnicujący poziom aktywności fizycznej polskiej populacji. Antropomotoryka. 2012; 59:17-29. 
13. Jones LW, Peppercorn J. Exercise research: early promise warrants further investment. Lancet Oncol. 2010; 11:408-410.

14. Didkowska J, Wojciechowska U. Zachorowania i zgony na nowotwory złośliwe w Polsce [Internet]. Warszawa: Krajowy Rejestr Nowotworów, Centrum Onkologii - Instytut im. Marii Skłodowskiej - Curie; c 2013 [updated 2013 Jul 31; cited 2015 Jul 10]. Available from: http://onkologia.org.pl/nowotwory-zlosliwe-ogolem-2/

15. Kruk J, Hassan Y, Aboul-Enein H Y. The role of physical activity in the prevention of cancer. Cancer Therapy. 2007; 5:169180.

16. Winnick JP. Adapted Physical Education and Sport. 4 ed. Champaign: Human Kinetics; 2005.

17. McTiernan A. Intervention studies in exercise and cancer prevention. Med Sci Sports Exerc. 2003; 35:1841-1845.

18. Lee IM. Physical activity and cancer prevention: data from epidemiologic studies. Med Sci Sports Exerc. 2003; 35(11):1823-7.

19. Schmitz KH, Courneya KS, Matthews C, Demark-Wahnefried W, Galvão DA, Pinto BM, at al. American College of Sports Medicine roundtable on exercise guidelines for cancer survivors. Med Sci Sports Exerc. 2010; 42:1409-1426.

20. Speck R M, Courneya K S, Mâsse L C, Duval S, Schmitz KH. An update of controlled physical activity trials in cancer survivors: a systematic review and meta-analysis. J Cancer Surviv, 2010; 4:87-100.

21. Biernat E, Stupnicki R, Gajewski A K. Międzynarodowy Kwestionariusz Aktywności Fizycznej (IPAQ) - wersja polska. Wychowanie Fizyczne i Sport. 2007; 51(1):47-54.

22. Craig CL, Marshall AJ, Sjöström M, Bauman AE, Booth ML, Ainsworth BE, at al. International Physical Activity Questionnaire: 12-country reliability and validity. Med Sci Sports Exerc. 2003; 35(8):1381-1395.

23. Booth M L. Assessment of physical activity: an international perspective. Res.Q.Exerc.Sport. 2000; 71:114-120.

24. Biernat E. Międzynarodowy Kwestionariusz Aktywności Fizycznej - Polska długa wersja. Medycyna Sportowa. 2013; 1(4), Vol. 29:1-15.

25. Piątkowska M. Wiek jako czynnik różnicujący poziom aktywności fizycznej polskiej populacji. Antropomotoryka. 2012; 59:17-29.

26. Jones LW, Peppercorn J. Exercise research: early promise warrants further investment. Lancet Oncol. 2010; 11:408-410.. 